Tersedia Online di: http://ojs.umrah.ac.id/index.php/gantang/index

\title{
EFEKTIFITAS PEMBELAJARAN DENGAN MEDIA KARTU UNTUK MENINGKATKAN KEMAMPUAN PEMAHAMAN MATEMATIS SISWA
}

\author{
Puji Lestari $^{1}$, Nina Sri Romdiani ${ }^{2}$ \\ 1neng_nji@yahoo.com, ${ }^{2}$ yushna2@gmail.com \\ ${ }^{1}$ IPI Garut, ${ }^{2} \mathrm{MA}$ Al Musadaddiyah Kabupaten Garut \\ 2018
}

\begin{abstract}
Abstrak
Metode pembelajaran dengan media kartu telah banyak digunakan sebagai salah satu metode yang cukup efektif dalam meningkatkan kemampuan belajar siswa. Dua diantaranya adalah metode Giving Question and Getting Answer (GQGA) dan metode Question Student Have (QSH). Tujuan penelitian ini adalah untuk menelaah efektifitas metode pembelajaran GQGA dan QSH dalam meningkatkan kemampuan pemahaman matematis siswa. Populasi dari penelitian ini adalah siswa kelas VIII SMPN 4 Tarogong Kidul Kabupaten Garut dengan sampel berjumlah 62 siswa. Metode yang digunakan adalah kuasi eksperimen dengan desain the statistic group pretest-posttest. Hasil uji statistik menunjukkan bahwa terdapat perbedaan peningkatan kemampuan pemahaman matematis siswa setelah diberikan metode GQGA dan QSH, yaitu rata-rata peningkatan kemampuan matematis siswa yang diberikan metode GQGA lebih tinggi daripada siswa yang diberikan metode QSH. Uji efek size terhadap kedua metode menunjukkan bahwa efektifitas kedua metode dalam meningkatkan kemampuan pemahaman matematis berada pada kategori sedang. Ini berarti pemanfaatan media kartu dalam pembelajaran cukup efektif dalam meningkatkan kemampuan pemahaman matematis siswa.
\end{abstract}

Kata kunci: kemampuan pemahaman matematis, metode GQGA, metode QSH.

\begin{abstract}
Learning methods with cards media have been widely used as one of the methods that are quite effective on enhancing students' learning ability. Two of them are Giving Question and Getting Answer (GQGA) and Question Student Have (QSH) methods. The aim of this research is to analyze the effectiveness of GQGA and QSH learning methods in improving students' mathematical understanding. The population of this research are $8^{\text {th }}$ grade students of State Junior High School Garut district and the sample are 62 students. This research used a quasi-experimental with pretest-posttest control group design. The result shows that there is a difference enhancement of students 'mathematical understanding ability after being given GQGA and QSH
\end{abstract}




\section{JURNAL GANTANG. Maret 2018; III(1): 17 - 23 \\ p-ISSN. 2503-0671 \\ e-ISSN. 2548-5547}

methods, which means that the enhancement of mathematical understanding ability of students who get GQGA method better than the students who get QSH method. The size effect of two methods is in the medium category. This means that the use of card media in learning is quite effective on enhancing students' mathematical understanding.

Keywords: mathematical understanding ability, GQGA method, QSH method.

\section{Pendahuluan}

Pemahaman merupakan tahap kedua (C2) dari tahapan ranah kognitif yang harus dikuasai oleh siswa. Pemahaman itu sendiri memiliki makna manakala siswa paham dan mengerti dengan isi materi yang dipelajari, siswa dapat menjelaskan suatu konsep yang telah dipahami dengan bahasanya sendiri, serta siswa dapat menyelesaikan permasalahan dalam materi tersebut. Hiebert (Copley, 2008) mengungkapkan bahwa, "We understand something if we see how it is related or connected to other things we know". Pernyataan tersebut bermakna bahwa ketika kita memahami sesuatu, ini berarti kita bisa mengaitkan pemahaman kita dengan hal lain yang telah kita ketahui sebelumnya.

Memahami konsep matematika, menjelaskan keterkaitan antar konsep dan mengaplikasikan konsep atau algoritma secara luwes, akurat, efisien dan tepat dalam pemecahan masalah merupakan salah satu tujuan penting dalam pembelajaran matematika di Indonesia (Permendiknas No 22 Tahun 2006). Berdasarkan tujuan tersebut dapat dikatakan bahwa salah satu kemampuan yang penting dan harus dikuasai adalah kemampuan pemahaman matematis.

Mengembangkan pemahaman matematis memiliki banyak keuntungan bagi siswa dalam berbagai arah. Tidak hanya siswa menjadi lebih kompeten dalam hal kemampuan komputasionalnya, namun juga dapat mengembangkan rasa percaya diri siswa terutama dalam kemampuan menyelesaikan masalah yang sifatnya lebih kompleks. Siswa dengan kemampuan pemahaman yang kuat, akan belajar bagaimana berfikir dan bernalar, dan bahkan terkadang akan merasa nyaman dalam mempelajari matematika. Berdasarkan hal tersebut penting kiranya untuk mengembangkan kemampuan pemahaman matematis siswa.

Beberapa ahli mengungkapkan definisi dari kemampuan pemahaman matematis seperti yang tertuang dalam Sumarmo dan Hendriana (2014), diantaranya Skemp yang menggolongkan pemahaman dalam dua tingkat, yaitu pemahaman instrumental dan pemahaman relasional. Pemahaman instrumental masuk dalam ketegori rendah yaitu hafal konsep/prinsip tanpa kaitan dengan yang lainnya, dan dapat menerapkan rumus dalam perhitungan sederhana, dan mengerjakan perhitungan secara algoritma, sedangkan pemahaman relasional masuk dalam kategori tinggi yaitu mengaitkan satu konsep/prinsip dengan konsep/prinsip lainnya.

Pengalaman penulis sebagai pendidik mengungkapkan bahwa masih banyak siswa yang kesulitan dalam memahami materi matematika. Umumnya siswa hanya berada pada level mengerti suatu konsep matematika, sehingga ketika diberikan sebuah tes untuk mengasah kemampuan pemahaman matematis siswa terhadap konsep matematika, siswa menemui kesulitan dalam mencari solusinya. Hal ini mengindikasikan bahwa kemampuan pemahaman matematis masih menjadi suatu hal yang sulit bagi siswa.

Peran aktif siswa dalam proses pembelajaran dan tercapainya pemahaman matematis siswa yang baik merupakan harapan dari seorang guru. Menurut Milati (2011: 16), strategi pembelajaran aktif adalah segala bentuk 
pembelajaran yang memungkinkan siswa secara aktif dalam proses pembelajaran itu sendiri baik dalam bentuk interaksi antar siswa maupun siswa dengan pengajar dalam proses pembelajaran tersebut. Dalam strategi pembelajaran aktif terdapat metode pembelajaran yang menggunakan media kartu yang dapat diharapkan dapat mendorong siswa untuk terlibat aktif dalam pembelajaran. Menurut Komariyah dan Soeparno (2010), pemanfaatan kartu dalam pembelajaran memiliki pengaruh yang signifikan terhadap hasil belajar siswa. Pemanfaatan media kartu yang diprediksi dapat menguji pemahaman siswa melalui pengajuan pertanyaan atau memaparkan jawaban yang dimiliki adalah metode Giving Question and Getting Answer (GQGA) dan metode Question Student Have (QSH).

Metode GQGA merupakan implementasi dari strategi pembelajaran kontrukstivistik yang menempatkan siswa sebagai subyek dalam pembelajaran. Proses pembelajaran dengan menggunakan metode GQGA dapat memberikan peluang siswa untuk berperan aktif menanyakan hal-hal yang belum dipahami, serta menjelaskan dan menyampaikan mengenai hal-hal yang sudah dipahami. Metode QSH dikembangkan untuk melatih peserta didik agar memiliki kemampuan dan keterampilan bertanya (Suprijono, 2012:108). Metode QSH dapat memberikan peluang siswa untuk berperan aktif bertanya mengenai hal-hal yang belum dipahami. Kedua metode tersebut dapat membangun siswa aktif dan memudahkan guru untuk mengetahui penguasaan siswa terhadap materi yang dipelajari, selain itu juga dapat membuat pembelajaran menjadi menyenangkan dan tidak menegangkan.

Berdasarkan pemaparan di atas, yang menjadi tujuan dalam penelitian ini adalah menelaah perbedaan peningkatan kemampuan pemahaman matematis siswa yang mendapatkan metode GQGA dan metode QSH, serta menelaah efektifitas dari kedua model tersebut terhadap kemampuan pemahaman matematis siswa.
Adapun kemampuan pemahaman matematis yang dikembangkan dalam penelitian ini adalah pemahaman relasional dengan 4 indikator yaitu menyatakan ulang konsep yang telah dipelajari, mengklasifikasikan objek-objek berdasarkan dipenuhi atau tidaknya persyaratan yang membentuk konsep tersebut, menerapkan konsep secara algoritma, dan menyajikan konsep dalam berbagai macam bentuk representasi matematika.

\section{Metode Penelitian}

Metode penelitian yang digunakan dalam penelitian ini metode kuasi eksperimen dengan desain penelitian the statistic group pretest-posttest. Teknik pengambilan sampel dalam penelitian ini secara purposive sampling. Jumlah sampel dari penelitian ini sebanyak 62 siswa yang terbagi menjadi 31 siswa yang memperoleh metode GQGA dan 31 siswa yang memperoleh metode QSH. Instrumen penelitian yang digunakan berupa tes kemampuan pemahaman matematis, sebanyak 11 butir soal uraian pada materi Lingkaran, Lembar Kerja Kelompok (LKK), dan Lembar Observasi Siswa. Instrumen tes telah memenuhi syarat validitas dengan nilai reliabilitas berkategori sedang.

Tehnik analisis data menggunakan analisa kuantiatif dengan bantuan program SPSS 20.0 dan program Microsoft Excel 2010. Data yang didapat dari hasil pretes dan postes, selanjutnya dihitung peningkatannya menggunakan uji Normalized Gain (N-Gain) dan untuk menguji perbedaan peningkatan kemampuan pemahaman matematis digunakan uji Mann-Whitney dikarenakan asumsi normalitas tidak terpenuhi, sedangkan untuk melihat efektifitas peningkatan kemampuan pemahaman matematis menggunakan uji effect size menurut Cohen (1992).

\section{Hasil dan Pembahasan}

Analisis data dimulai dari data pretes dengan melakukan uji perbedaan kelompok terhadap siswa yang mendapatkan metode GQGA dan metode QSH. Deskripsi hasil analisis 
JURNAL GANTANG. Maret 2018; III(1): 17 - 23

p-ISSN. 2503-0671

e-ISSN. 2548-5547

data disajikan dalam tabel berikut 1 .

Selanjutnya dilakukan uji dua pihak

dan QSH dengan menggunakan uji-t menyimpulkan bahwa tidak terdapat perbedaan terhadap data pretes siswa diantara kedua kelompok, dan hasil perhitungannya disajikan dalam tabel 2.

Dari Tabel 2 diperoleh informasi bahwa berdasarkan hasil uji dua pihak terhadap data kemampuan awal siswa kedua kelas. Selanjutnya dilakukan uji dua pihak untuk melihat perbedaan peningkatan kemampuan pemahaman matematis siswa antar kedua kelompok yang di deskripsikan dalam tabel 3.

Tabel 1 Statistik Deskriptif Kemampuan Pemahaman Matematis Siswa

\begin{tabular}{ccccccc}
\hline \multirow{2}{*}{ Data Statistik } & \multicolumn{3}{c}{ Metode GQGA } & \multicolumn{3}{c}{ Metode QSH } \\
\cline { 2 - 7 } $\mathbf{N}$ & Pretest & Posttest & N-Gain & Pretest & Posttest & N-Gain \\
$\mathbf{X}_{\text {maks }}$ & 31 & 31 & 31 & 31 & 31 & 31 \\
$\mathbf{X}_{\text {min }}$ & 24 & 44 & 1,00 & 19 & 39 & 0,85 \\
$\bar{X}$ & 2 & 7 & 0,03 & 3 & 9 & $-0,21$ \\
Persentase & 11,03 & 28,65 & 0,55 & 10,39 & 23,52 & 0,39 \\
$(\boldsymbol{\%})$ & 25 & 65 & 55 & 24 & 54 & 39 \\
SD & 4,58 & 10,82 & 0,31 & 3,45 & 8,77 & 0,28 \\
\hline
\end{tabular}

Tabel 2 Ringkasan Uji Statistik Kemampuan Awal Siswa

\begin{tabular}{|c|c|c|c|c|}
\hline Pembelajaran & $\mathbf{N}$ & Normalitas & Homogenitas & $\begin{array}{c}\text { Uji Perbedaan Dua } \\
\text { Rerata }\end{array}$ \\
\hline $\begin{array}{l}\text { Metode } \\
\text { GQGA }\end{array}$ & 31 & $\begin{array}{l}\text { Berdistribusi } \\
\text { Normal }\end{array}$ & $\begin{array}{l}\text { Varians } \\
\text { Homogen }\end{array}$ & $\begin{array}{c}\text { Tidak terdapat } \\
\text { perbedaan } \\
\text { kemampuan awal }\end{array}$ \\
\hline Metode QSH & 31 & $\begin{array}{l}\text { Berdistribusi } \\
\text { Normal }\end{array}$ & $\begin{array}{l}\text { Varians } \\
\text { Homogen }\end{array}$ & $\begin{array}{c}\text { siswa yang mendapat } \\
\text { metode GQGA dan } \\
\text { QSH }\end{array}$ \\
\hline
\end{tabular}

Tabel 3 Ringkasan Uji Statistik Peningkatan Kemampuan Matematis

\begin{tabular}{clc}
\hline Pembelajaran & Normalitas & Uji Perbedaan Dua Rerata \\
\hline Metode GQGA & Berdistribusi & Terdapat perbedaan \\
& Normal & peningkatan kemampuan \\
Metode QSH & Tidak & pemahaman matematis siswa \\
& Berdistribusi & yang mendapat metode \\
& Normal & GQGA dengan QSH \\
\hline
\end{tabular}


Hasil uji perbandingan peningkatan kedua kelompok seperti terlihat dalam tabel 3 menyimpulkan bahwa terdapat perbedaan peningkatan kemampuan matematis antara siswa yang mendapatkan metode GQGA dan metode QSH. Kelompok siswa yang mendapatkan metode GQGA menunjukkan peningkatan dengan persentase rata-rata peningkatannya sebesar $55 \%$ dan termasuk ke dalam kriteria sedang. Kelompok siswa yang mendapatkan metode Question Student Have (QSH) juga menunjukkan peningkatan kemampuan pemahaman matematis siswa dengan persentase rata-rata peningkatannya sebesar 39\% dan termasuk ke dalam kriteria sedang. Walaupun peningkatan kemampuan pemahaman matematis keduanya termasuk ke dalam kriteria sedang, pada kelas yang mendapatkan metode GQGA persentase jumlah siswa yang mengalami peningkatan pemahaman matematis dengan kriteria tinggi sebesar 38,7\%, dengan kriteria sedang sebesar $35,5 \%$, dan rendah sebesar $25,8 \%$. Untuk kelas yang mendapatkan metode QSH persentase jumlah siswa yang mengalami peningkatan pemahaman matematis dengan kriteria tinggi sebesar $6,5 \%$, dengan kriteria sedang sebesar 54,8\%, dan rendah sebesar $38,7 \%$. Berdasarkan hasil persentase ini dapat dicermati secara sekilas bahwa untuk kelas yang mendapatkan metode GQGA jumlah siswa yang mengalami peningkatan kemampuan pemahaman matematis dengan kriteria tinggi lebih banyak jika dibandingkan siswa pada kelas yang mendapatkan metode QSH. Sebaliknya, siswa yang mengalami peningkatan dengan kategori rendah pada kelas yang menggunakan metode GQGA lebih sedikit dibandingkan siswa pada kelas yang menggunakan metode QSH.

Adanya perbedaan peningkatan kemampuan pemahaman matematis antara kedua metode juga terlihat dari sintaks pembelajarannya. Walaupun kedua kelas sama-sama menggunakan media kartu akan tetapi dalam pelaksanaan pembelajarannya, siswa yang menggunakan metode GQGA lebih efektif dibandingkan dengan siswa yang menggunakan metode QSH. Berikut ini diperlihatkan perbedaan dari pelaksanaan pembelajaran dengan metode GQGA dan metode QSH yang merupakan hasil adaptasi terhadap sintaks pembelajaran berdasarkan Silberman(2007):

Tabel 4 Deskripsi Langkah Pembelajaran Kelas GQGA dan Kelas QSH

\begin{tabular}{|c|c|c|}
\hline \multirow{2}{*}{ No. } & \multicolumn{2}{|c|}{ Langkah Pembelajaran Siswa pada Kegiatan Inti } \\
\hline & Metode GQGA & Metode QSH \\
\hline 1 & $\begin{array}{l}\text { Menerima potongan-potongan } \\
\text { pertanyaan (berupa kartu) dan kertas } \\
\text { jawaban yang guru bagikan. } \\
\text { Mengkondisikan diri untuk bergabung } \\
\text { dengan anggota kelompoknya. }\end{array}$ & 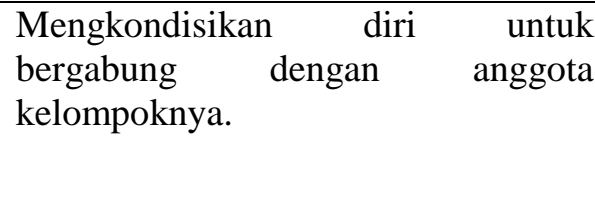 \\
\hline 2 & $\begin{array}{l}\begin{array}{l}\text { Menerima } \\
\text { (LKK). }\end{array} \\
\text { Lembar }\end{array}$ & $\begin{array}{l}\text { Memperhatikan penjelasan guru } \\
\text { mengenai materi yang dipelajari. }\end{array}$ \\
\hline 3 & $\begin{array}{l}\text { Memperhatikan penjelasan guru mengenai } \\
\text { materi. }\end{array}$ & $\begin{array}{l}\text { Menanyakan atau menjawab } \\
\text { pertanyaan mengenai materi. }\end{array}$ \\
\hline 4 & $\begin{array}{l}\text { Siswa mendiskusikan dan menyelesaikan } \\
\text { permasalahan pada LKK }\end{array}$ & Menerima Lembar Kerja Kelompok. \\
\hline 5 & $\begin{array}{l}\text { Melengkapi kertas } 1 \text { atau kertas } 2 \text { sesuai } \\
\text { dengan masalah yang didapatkan pada }\end{array}$ & $\begin{array}{l}\text { Mengerjakan Lembar } \\
\text { Kelompok (LKK). }\end{array}$ \\
\hline
\end{tabular}


JURNAL GANTANG. Maret 2018; III(1): 17 - 23

p-ISSN. 2503-0671

e-ISSN. 2548-5547

\begin{tabular}{|c|c|c|}
\hline & LKK & \\
\hline 6 & $\begin{array}{l}\text { Menemukan apa yang belum dipahami dan } \\
\text { apa yang sudah dipahami. Masing-masing } \\
\text { kelompok memilih salah satu pernyataan } \\
\text { yang ada di kertas } 1 \text { dan kertas } 2 \text {. }\end{array}$ & $\begin{array}{l}\text { Setiap kelompok menerima kertas } \\
\text { kosong (berupa kartu) dan } \\
\text { mendiskusikan pertanyaan yang akan } \\
\text { dijadikan milik kelompok sesuai } \\
\text { dengan lembar kerja kelompok. }\end{array}$ \\
\hline 7 & $\begin{array}{l}\text { Menyiapkan diri untuk membacakan } \\
\text { pernyataan, dan menjawabnya. (Salah satu } \\
\text { siswa dalam kelompok menjawab } \\
\text { pernyataan tersebut. Jika tidak ada yang } \\
\text { bisa menjawab maka kelompok lain } \\
\text { dipersilahkan untuk menanggapi langsung, } \\
\text { jika tidak ada yang bisa menjawab maka } \\
\text { guru yang menjawabnya) }\end{array}$ & $\begin{array}{l}\text { Menuliskan pertanyaan yang dimiliki } \\
\text { kelompok pada kertas pertanyaan. }\end{array}$ \\
\hline 8 & $\begin{array}{lccrr}\text { Menyiapkan } & \text { diri } & \text { untuk } & \text { membacakan } \\
\text { pernyataan } & \text { pada } & \text { kertas } & 2 & \text { dan } \\
\text { menjelaskannya. } & & & \end{array}$ & $\begin{array}{l}\text { Menyerahkan kartu kepada setiap } \\
\text { kelompok searah jarum jam, ketika } \\
\text { kembali lagi kepada kelompok yang } \\
\text { menulisnya, maka dihitung tanda } \\
\text { centang yang berada pada kartu } \\
\text { pertanyaan tersebut. }\end{array}$ \\
\hline 9 & $\begin{array}{l}\text { Menanggapi konfirmasi jawaban soal } \\
\text { LKK. } \\
\begin{array}{l}\text { Memperhatikan guru } \\
\text { menjelaskan. }\end{array}\end{array}$ & $\begin{array}{l}\text { Memperhatikan } \\
\text { jawaban yang dan menyimak } \\
\text { guru. }\end{array}$ \\
\hline
\end{tabular}

Secara deskripsi, ada sintaks pembelajaran pada metode QSH yang cukup menyita waktu sehingga dirasa pembelajaran menjadi kurang efektif, yaitu sintaks pada nomor 8. Hal ini menyebabkan siswa yang mendapatkan metode ini cenderung menjadi tidak fokus pada tahapan pembelajaran tersebut sehingga ketika pada proses siswa seharusnya mengungkapkan pertanyaan yang dimiliki, siswa malah cenderung mengikuti pertanyaan pada kelompok lainnya. Hal ini diprediksi menjadi salah satu penyebab adanya perbedaan peningkatan kemampuan pemahaman matematis siswa pada kedua metode.

Selain dilakukan uji perbandingan antara kedua kelompok, dilakukan juga uji efek size untuk mengetahui seberapa besar efektifitas penggunaan metode pembelajaran dengan media kartu dalam meningkatkan kemampuan pemahaman matematis siswa.

Interpretasi efektifitas menggunakan kriteria dari Cohen pada tahun 1988 (Becker, 2000) dengan rumus sebagai berikut:

$$
d=\frac{\text { selisih rerata }}{\text { simpangan baku }}
$$

$$
S_{B}=\sqrt{\frac{\left(n_{1}-1\right) S_{1}{ }^{2}+\left(n_{2}-1\right) S_{2}{ }^{2}}{\left(n_{1}-1\right)+\left(n_{2}-1\right)}}
$$

Hasil perhitungan menunjukkan efektifitas bernilai 0,30 dan efektifitas berada pada kategori sedang. Ini berarti pemanfaatan media kartu dalam pembelajaran memberikan kontribusi terhadap peningkatan kemampuan pemahaman matematis siswa serta dapat dikatakan cukup efektif dalam meningkatkan kemampuan pemahaman matematis siswa.

\section{Penutup}

Peningkatan kemampuan pemahaman matematis siswa yang mendapat metode GQGA dan metode QSH memiliki perbedaan yang signifikan. Hal ini diakibatkan beberapa faktor diantaranya pengaruh sintaks pembelajaran pada kedua metode. Kontribusi metode pembelajaran 
terhadap kemampuan pemahaman matematis yang diuji lewat uji efek size berkategori sedang, ini berarti bahwa model pembelajaran dengan memanfaatkan media kartu cukup efektif dalam meningkatkan kemampuan pemahaman matematis siswa. Oleh karena itu, baik metode GQGA maupun metode QSH cukup baik untuk dapat diadopsi oleh para guru ataupun pendidik dalam pembelajaran matematika di kelas khususnya pada materi lingkaran.

\section{Referensi}

Cohen, J. (1992). A Power Prime. Psychological Bulletin, 1992, Vol.112, No.1, 155-159.

Becker, L.A. (2000). Effect Size (ES). $<$ http://web.uccs.edu/lbecker/Psy590/es.ht $\mathrm{m}>$

Copley, J. (2008). Teaching for Conceptual Understanding: Exciting Mathematics. Scott Foresman - Addison Wesley: enVisionMATH.

Dimyati, dan Mudjiono. (2006). Belajar dan Pembelajaran. Jakarta: Rineka Cipta

Komariyah, Z \& Soeparno. (2010). Pengaruh Pemanfaatan Media Permainan Kartu Hitung Terhadap Hasil Belajar Siswa Materi Ajar Operasi Hitung Campuran Mata Pelajaran Matematika Kelas III Sdn Babat Jerawat I Surabaya. [online]. Tersedia:ejournal.unesa.ac.id/article/7337 /73/article.pdf

Milati, N. (2011). Penerapan Strategi Pembelajaran Aktif Teknik Question Student Have untuk Meningkatkan Perhatian Siswa dalam Pembelajaran Matematika PTK. Skripsi pada Program Matematika Fakultas Ilmu Tarbiyah dan Keguruan UIN Syarif Hidayatullah. Jakarta: tidak diterbitkan. [online].

Tersedia:

repository.uinjkt.ac.id $>$ dspace $>$ bitstream.

Permendiknas No 22 Tahun 2006.

Silberman, Melvin L. (2007). Active Learning Strategi Pembelajaran Aktif. Yogyakarta: Pustaka Insan Madani.

Soemarmo, U dan Hendriana, H. (2014).
Penilaian Pembelajaran Matematika. Bandung: Refika Aditama

Suprijono, A. (2012). Cooperative Learning: Teori dan Aplikasi PAIKEM. Yogyakarta: Pustaka Pelajar. 
JURNAL GANTANG. Maret 2018; III(1): 17 - 23

p-ISSN. 2503-0671

e-ISSN. 2548-5547 